\title{
Genomics as a means to understand bacterial phylogeny and ecological adaptation: the case of bifidobacteria
}

\author{
Marco Ventura - Carlos Canchaya - Gerald F. Fitzgerald • \\ Radhey S. Gupta · Douwe van Sinderen
}

Published online: 26 June 2007

(C) Springer Science+Business Media B.V. 2007

\section{Corrigendum to: Antonie van Leeuwenhoek (2007) 91:351-372 \\ DOI 10.1007/s10482-006-9122-6}

Regrettably, the description of plasmid $\mathrm{p} 4 \mathrm{M}$ was not properly referenced in the original publication.

On page 354, it reads "and p4M from B. pseudocatenulatum (Sgorbati et al. 1982),"

when it should have read "and p4M from $B$. pseudocatenulatum (Gibbs et al. 2006),"
The full reference is published below:

Gibbs MJ, Smeianov VV, Steele JL, Upcroft P, Efimov BA (2006) Two families of rep-like genes that probably originated by interspecies recombination are represented in viral, plasmid, bacterial, and parasitic protozoan genomes. Mol Biol Evol 23:1097-1100.

The online version of the original article can be found under doi: 10.1007/s10482-006-9122-6.

M. Ventura $(\bowtie)$

Department of Genetics, Anthropology and Evolution, University of Parma, Parco Area delle Scienze 11a, Parma 43100, Italy

e-mail: marco.ventura@unipr.it

C. Canchaya - G. F. Fitzgerald · D. van Sinderen Alimentary Pharmabiotic Centre and Department of Microbiology, BioSciences Institute, National University of Ireland, Cork, Ireland

R. S. Gupta

Department of Biochemistry and Biomedical Sciences, McMaster University, Hamilton, Canada 